\title{
Redescription and resolution of some Neotropical species of jumping spiders described by Caporiacco and description of a new species (Araneae: Salticidae)
}

\author{
Gustavo R. S. Ruiz \& Antonio D. Brescovit
}

Laboratório de Artrópodes, Instituto Butantan. Avenida Vital Brazil 1500, 05503-900 São Paulo, São Paulo, Brasil. E-mail: gustavoruiz86@hotmail.com,adbresc@terra.com.br

\begin{abstract}
Type specimens of some of Caporiacco's Neotropical species are revised. The taxonomy of his species from French Guiana, whose type specimens are lost, is considered. The types of Corythalia hadzji Caporiacco, 1947, Corythalia luctuosa Caporiacco 1954, Hypaeus barromachadoi Caporiacco, 1947 and Naubolus melloleitaoi Caporiacco, 1947 are redescribed. The following new synonymies are established: Freya guianensis Caporiacco, 1947 = Chira spinipes (Taczanowski, 1871) syn. nov.; Hypaeus bivittatus Caporiacco, 1947 = Hypaeus barromachadoi Caporiacco, 1947 syn. nov. New combinations are: Agelista petrusewiczi Caporiacco, 1947 = Noegus petrusewiczi (Caporiacco, 1947) comb. nov.; Albionella chickeringi Caporiacco, 1954 = Mago chickeringi (Caporiacco, 1954) comb. nov.; Asaracus pauciaculeis Caporiacco, 1947 = Mago pauciaculeis (Caporiacco, 1947) comb. nov.; Cerionesta leucomystax Caporiacco, 1947 = Sassacus leucomystax (Caporiacco, 1947) comb. nov.; Lapsias guianensis Caporiacco, 1947 = Cobanus guianensis (Caporiacco, 1947) comb. nov.; Phiale modestissima Caporiacco, $1947=$ Asaracus modestissimus (Caporiacco, 1947) comb. nov. The species Noegus lodovicoi sp. nov. is also described, based on an ex-syntype of Agelista petrusewiczi. The following nominal species are considered species inquirendae: Albionella guianensis Caporiacco, 1954, Alcmena trifasciata Caporiacco, 1954, Amycus effeminatus Caporiacco, 1954, Capidava variegata Caporiacco, 1954, Corythalia variegata Caporiacco, 1954, Dendryphantes coccineocinctus Caporiacco, 1954, Dendryphantes gertschi Caporiacco, 1947, Dendryphantes spinosissimus Caporiacco, 1954, Ilargus modestus Caporiacco, 1947, Lapsias melanopygus Caporiacco, 1947 = Frigga melanopygus (Caporiacco, 1947) comb. nov., Lurio splendidissimus Caporiacco, 1954, Nagaina modesta Caporiacco, 1954, Amycus patellaris (Caporiacco, 1954), Phidippus triangulifer Caporiacco, 1954 and Tutelina iridea Caporiacco, 1954.

KEY WORDS. French Guiana; Guyana; taxonomy; Venezuela.
\end{abstract}

RESUMO. Redescrição e resolução de algumas espécies neotropicais de aranhas papa-moscas descritas por Caporiacco e descrição de uma espécie nova (Araneae: Salticidae). Os espécimes-tipo de algumas espécies neotropicais descritas por Caporiacco são revisados. A taxonomia de suas espécies da Guiana Francesa, cujos espécimes-tipo estão perdidos, é discutida. Os tipos de Corythalia hadzji Caporiacco, 1947, Corythalia luctuosa Caporiacco 1954, Hypaeus barromachadoi Caporiacco, 1947 e Naubolus melloleitaoi Caporiacco, 1947 são redescritos. As seguintes novas sinonímias são estabelecidas: Freya guianensis Caporiacco, 1947 = Chira spinipes (Taczanowski, 1871) syn. nov.; Hypaeus bivittatus Caporiacco, $1947=$ Hypaeus barromachadoi Caporiacco, 1947 syn. nov. Também são apresentadas as novas combinações: Agelista petrusewiczi Caporiacco, 1947 = Noegus petrusewiczi (Caporiacco, 1947) comb. nov.; Albionella chickeringi Caporiacco, $1954=$ Mago chickeringi (Caporiacco, 1954) comb. nov.; Asaracus pauciaculeis Caporiacco, 1947 = Mago pauciaculeis (Caporiacco, 1947) comb. nov.; Cerionesta leucomystax Caporiacco 1947 = Sassacus leucomystax (Caporiacco, 1947) comb. nov.; Lapsias guianensis Caporiacco, 1947 = Cobanus guianensis (Caporiacco, 1947) comb. nov.; Phiale modestissima Caporiacco, $1947=$ Asaracus modestissimus (Caporiacco, 1947) comb. nov. A espécie Noegus lodovicoi sp. nov. também é descrita, baseada em um exsíntipo de Agelista petrusewiczi. As seguintes espécies nominais são consideradas species inquirendae: Albionella guianensis Caporiacco, 1954, Alcmena trifasciata Caporiacco, 1954, Amycus effeminatus Caporiacco, 1954, Capidava variegata Caporiacco, 1954, Corythalia variegata Caporiacco, 1954, Dendryphantes coccineocinctus Caporiacco, 1954, Dendryphantes gertschi Caporiacco, 1947, Dendryphantes spinosissimus Caporiacco, 1954, Ilargus modestus Caporiacco, 1947, Lapsias melanopygus Caporiacco, 1947 = Frigga melanopygus (Caporiacco, 1947) comb. nov., Lurio splendidissimus Caporiacco, 1954, Nagaina modesta Caporiacco, 1954, Amycus patellaris (Caporiacco, 1954), Phidippus triangulifer Caporiacco, 1954 e Tutelina iridea Caporiacco, 1954.

PALAVRAS-CHAVE. Guiana; Guiana Francesa; taxonomia; Venezuela.

Lodovico di Caporiacco described 85 species and proposed 10 genera of jumping spiders from the Neotropical Region (CAPORIACCO 1938, 1947, 1948, 1954, 1955), contributing substantially to the knowledge on Neotropical diversity of salticids. Of these, one species was described from Guatemala and Mexico (Caporiacco 1938), 41 species from Guyana

Revista Brasileira de Zoologia 25 (3): 487-494, September, 2008 
(CAPORIACCO 1947, 1948), 25 from French Guiana (CAPORIACCO 1954) and 18 from Venezuela (CAPORIACCo 1955). All his descriptions, especially his drawings, were very poor in details and until recently no modern taxonomist had had the opportunity to examine the type specimens of many of his species; therefore most of them have remained unrecognizable.

RuIz \& BRESCOVIT (2005) examined the type specimens of some of his species from Venezuela and established several taxonomic changes. Some of Caporiacco's species from Guyana were also revised by Ruz et al. (2007), but most of his taxa from that country are revised in the present paper. The single species from Guatemala/Mexico and the 25 from French Guiana are the most taxonomically problematic, due to his bad illustrations and the fact that almost all of the type specimens are lost.

According to Galiano (1968b), who visited the Muséum National d'Histoire Naturelle (MNHN, Paris) and redescribed all Neotropical species described by Eugène Simon, the type specimens of the species described from French Guiana by CAPORIACCO (1954), that should be deposited in the collection of the MNHN, were sent to Caporiacco and have never been sent back to Paris. BERDONDINI \& WhitMan (2002) published a list of all the types deposited in the collection of the Museo Zoologico de "La Specola". The only Caporiacco species from French Guiana with specimens in that collection are Albionella guianensis Caporiacco, 1954, Alcmena trifasciata Caporiacco, 1954, Chira portai Caporiacco, 1954 [= Frigga kessleri (Taczanowski, 1872)], Corythalia luctuosa Caporiacco, 1954 and Mago budoninus Caporiacco, 1954 [= Hypaeus taczanowskii (Mello-Leitão, 1948)]. Among the 25 species described in that paper (CAPORIACCO 1954), only these five were described based on syntypes, while the other 20 were based on single specimens. This makes us wonder if Caporiacco retained only duplicates and indeed sent the rest of the specimens back to Paris. The fact is that those types are lost.

After the two previous papers on the taxonomy of those problematical species (RuIz \& BRESCOvit 2005; RuIz et al. 2007), the present study is a third attempt to clarify the identity of Caporiacco's Neotropical species.

\section{MATERIAL AND METHODS}

The material examined is deposited in the Museo Zoologico de "La Specola", Firenze. The measurements are given in millimeters. The abbreviations used throughout the text are (RTA) retrolateral tibial apophysis, (AME) anterior median eye, (MNHN) Muséum National d'Histoire Naturelle, (MZLS) Museo Zoologico de "La Specola".

\section{Amycinae Simon, 1901 Hypaeus barromachadoi Caporiacco, 1947} Figs 1-3

Hypaeus barromachadoi Caporiacco, 1947: 30 (male holotype from Itamyaruma, Essequibo River, Guyana, 29.VII.1936, C. Romiti leg., deposited in MZLS 551, examined); Caporiacco, 1948: 698, fig. 122; Berdondini \& Whitman, 2002: 144; Platnick, 2008. Hypaeus bivittatus Caporiacco, 1947: 30 (Male holotype from Conwarook, Potaro, Guyana, 18.V.1936, C. Romiti leg., deposited in MZLS 553, examined); Caporiacco, 1948: 699, fig. 123; Berdondini \& Whitman, 2002: 144; Platnick, 2008. Syn. nov.

Description. Male (holotype of $H$. barromachadoi). Total length 6.30. Carapace dark brown, 2.90 long, 2.10 wide and 1.70 high. Ocular quadrangle 1.75 long, cephalic region light brown. Anterior eye row 1.95 wide and posterior 1.85 wide. Diameter of AME 0.75. Clypeus 0.25 high. Chelicerae dark brown, with low prodorsal humps (Fig. 1), four promarginal and three retromarginal teeth. Palps as in Figs 2-3, light brown, with a short embolus and a bifid RTA. Endites, labium and sternum light brown. Legs I dark brown, II-IV light brown. Abdomen dark brown, variegated, with a pair of lateral light brown stripes on the posterior two thirds. The other specimen has a yellow abdomen with a pair of paramedian longitudinal dark brown stripes dorsally.

Female. Unknown.

Remarks. Both species were treated as inquirendae by GALIANO (1968b: 318).

\section{Mago chickeringi (Caporiacco, 1954) comb. nov.}

Albionella chickeringi Caporiacco, 1954: 153, figs 50, 50a-b (Male holotype from Charvein, French Guiana, 1914, R. Benoist leg., deposited in MNHN, lost, not examined); Platnick, 2008.

Remarks. Although the type specimen is lost, the illustration of the male palp by the author, as an exception, can allow the species identification for future works on the local fauna. The species seems to belong in the genus Mago O.P.Cambridge, 1882 and is similar to Mago procax Simon, 1900 by having a slender, short embolus (See GaLiano 1963a, pl. 27, fig. 7). Mago chickeringi, though, can be distinguished from all the revised species of the genus for uniquely having a thin, dorsally curved RTA (See CAPORIACCO 1954, fig. 50a).

\section{Mago pauciaculeis (Caporiacco, 1947) comb. nov. Figs 4-6}

Asaracus pauciaculeis Caporiacco, 1947: 32 (Female holotype from Garroway Landing, Potaro River, Guyana, 30.III.1936, C. Romiti leg., deposited in MZLS 568, examined); Caporiacco, 1948: 714, fig. 144; Berdondini \& Whitman, 2002: 147; Platnick, 2008.

Description. Female (holotype). Total length 6.80. Body uniformly yellow. Carapace 3.55 long, 1.72 wide, 1.25 high. Ocular quadrangle 1.55 long. Anterior eye row 1.70 wide and posterior 1.45 wide. Chelicerae with three or four teeth on promargin and four or five on retromargin. Epigynum (Figs 46) with a wide pocket and two rounded copulatory openings; internally with a pair of long, narrow digitiform glands and spermathecae as thick as the copulatory ducts.

Male. Unknown. 


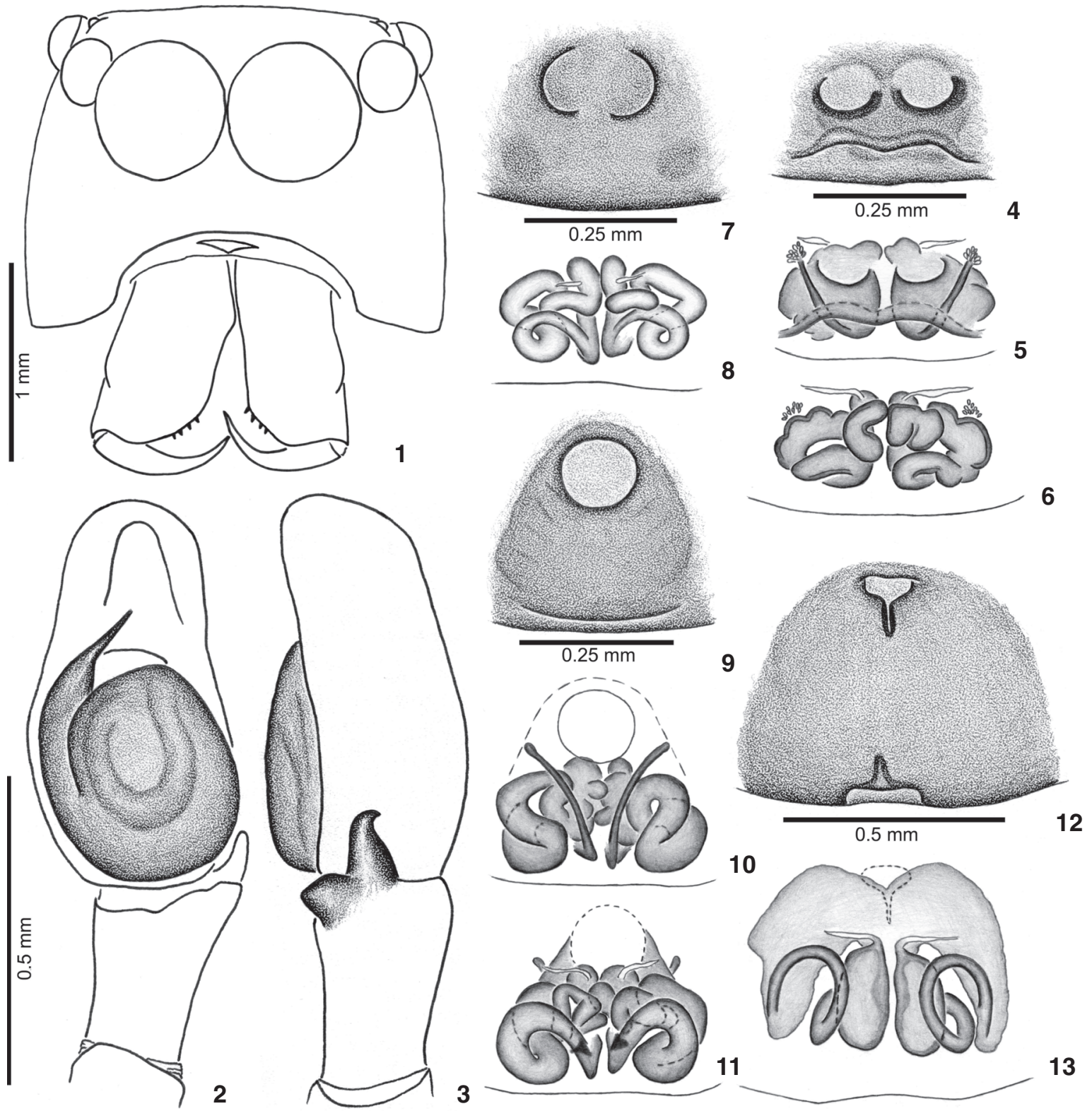

Figures 1-13. (1-3) Hypaeus barromachadoi: (1) male chelicerae and face; (2) male palp, ventral view; (3) retrolateral view; (4-6) Mago pauciaculeis: (4) female epigynum, ventral view; (5) ventral view, cleared; (6) dorsal view, cleared; (7-8) Noegus petrusewiczi: (7) female epigynum, ventral view; (8) dorsal view, cleared; (9-11) Noegus lodovicoi sp. nov.: (9) female epigynum, ventral view; (10) ventral view, cleared; (11) dorsal view, cleared; (12-13) Asaracus modestissimus: (12) female epigynum, ventral view; (13) dorsal view, cleared.

\section{Noegus petrusewiczi (Caporiacco, 1947) comb. nov.} Figs 7-8

Agelista petrusewiczi Caporiacco, 1947: 31 (Female lectotype, here designated, from Tumatumarí, Guyana, 21.VII.1936, C. Romiti leg., deposited in MZLS 567, examined); Caporiacco, 1948: 704; Berdondini \& Whitman, 2002: 147; Platnick, 2008.

Description. Female (lectotype). Total length: 5.50. Cara- pace yellow. Chelicera yellow, with four promarginal and three retromarginal teeth. Palp and legs yellow. Abdomen and spinnerets pale. Epigynum with a pair of semicircular copulation openings and internally with long copulation ducts (Figs 7-8). Male. Unknown.

Remarks. The species was considered nomen dubium by GaLIANO (1963b: 32). It was described based on two female syntypes, which, after a detailed comparison, do not belong to the same 
species. Although the lectotype, here designated, does not have the standard dentition of Noegus (two small promarginal teeth), the species is tentatively transferred to this genus. The lectotype designated (Figs 7-8) is the specimen that fits the original description, with four promarginal and three retromarginal teeth. Because taxonomy of the group is still in need of revision, we decline to present a diagnosis for the species.

\section{Noegus lodovicoi sp. nov. Figs 9-11}

Type. Female holotype (ex-syntype of Agelista petrusewiczi Caporiacco, 1947) from Conwarook, Guyana, 18.V.1936, C. Romiti leg., deposited in MZLS 566.

Description. Female. Total length: 5.50. Carapace yellow. Chelicera yellow, with three teeth on both promargin and retromargin. Palp and legs yellow. Abdomen and spinnerets pale. Epigynum with a rounded atrium placed far from the posterior border; internally with very long copulation ducts and a pair of long glandular projections, directed forward, arising from their initial part (Figs 9-11).

Male. Unknown.

Remarks. The specimen is poorly preserved but, despite not having the standard dentition of Noegus (two promarginal teeth), its epigynum is very similar to that of Noegus trilineatus MelloLeitão, 1940 and seems to be correctly placed in this genus.

\section{Amycoida Maddison \& Hedin, 2003 incertae sedis Asaracus modestissimus (Caporiacco, 1947) comb. nov.}

\section{Figs 12-13}

Phiale modestissima Caporiacco, 1947: 31 (Female holotype from Itamyaruma, Essequibo River, Guyana, 24.VII.1936, C. Romiti leg., deposited in MZLS 589, examined); Caporiacco, 1948: 709; Berdondini \& Whitman, 2002: 147; Platnick, 2008.

Description. Female (holotype). Total length: 9.50. Body uniformly light brown, except for a pair of light brown marks and a longitudinal median light brown short stripe on the posterior third of the yellow abdomen. Carapace 3.40 long, 2.40 wide and 1.70 high. Ocular quadrangle 1.90 long. Anterior eye row 2.05 wide and posterior 1.90 wide. Chelicerae stout, with one retromarginal and two promarginal teeth. Epigynum (Figs 12-13) with a posterior small pocket and an anterior small atrium joining the copulatory openings; initial part of copulatory ducts very membranous and wide; sclerotized narrow ducts coil from the posterior part of the membranous ducts toward the spermathecae, which are medially placed.

Male. Unknown.

\section{Dendryphantinae Menge, 1879 Naubolus melloleitaoi Caporiacco, 1947}

Figs $14-15$

Naubolus mello-leitãoi Caporiacco, 1947: 34 (Penultimate male with palp structures already sclerotized from Webecari Mis- sion, Essequibo, Guyana, 3.IV.1936, C. Romiti leg., deposited in MZLS 550, examined); Caporiacco, 1948: 730. Naubolus melloleitaoi; Roewer, 1955: 1270; Platnick, 2008.

Description. Male (holotype). Total length: 4.80. Carapace brown, 1.90 long, 1.47 wide, 0.80 high, with a pair of longitudinal dorsolateral stripes of white scales. Ocular quadrangle 0.92 long. Anterior eye row 1.25 wide, posterior 1.32 wide. Chelicera and palp brown; palp with a well developed embolic haematodocha and a short embolus directed to the prolateral side of the palp (Figs 14-15). Abdomen dorsally light brown with a pair of longitudinal stripes of white scales that are fused anteriorly; laterally brown, ventrally faded light brown.

Female. Unknown.

Remarks. The holotype, in the penultimate instar, allows the identification of the species. Its position in Naubolus is doubtful, since the boundaries of genera in Dendryphantinae are in need of revision.

\section{Sassacus leucomystax (Caporiacco, 1947) comb. nov. Figs 16-17}

Cerionesta leucomystax Caporiacco, 1947: 34 (Male lectotype and two male paralectotypes, here designated, from Conwarook, Potaro, Guyana, 18.V.1936, Webecari Mission, Essequibo, Guyana, 3.IV.1936, Garroway Landing, 21.III.1936, all C. Romiti leg., deposited in MZLS 586, 585+1 vial with no number, respectively); Caporiacco, 1948: 730, fig. 164; Platnick, 2008.

Description. Male (lectotype). Total length: 2.82 . Carapace dark brown, 1.42 long, 1.15 wide, 0.82 high, with dorsolateral longitudinal stripes of white scales joining the eyes and extending to posterior border of carapace. Ocular quadrangle 0.72 long. Anterior eye row 0.92 wide, posterior 1.02 wide. Chelicera dark brown, with two teeth on promargin, one distally placed on retromargin; chelicerae slightly divergent. Palp dark brown, with a curved femur; small tuft of white scales on distal dorsal palpal femur, a sinuous RTA, embolic haematodocha hidden behind the tegulum and a well developed embolus (Figs 16-17). Legs 1423, dark brown; patellae and tarsi lighter. Abdomen light brown with a transverse stripe of white scales on the anterior border; dorsally with a chevron of white scales in the middle of abdomen and two others on the posterior half.

Female. Unknown.

\section{Euophryinae Simon, 1901 Cobanus guianensis (Caporiacco, 1947) comb. nov.} Figs 18-19

Lapsias guianensis Caporiacco, 1947: 30 (Male holotype from Conwarook, Potaro River, Guyana, 18.V.1936, C. Romiti leg., deposited in La Specola 558, examined); Caporiacco, 1948: 701, fig. 126; Berdondini \& Whitman, 2002: 146; Platnick, 2008.

Description. Male (holotype). Total length 6.30. Carapace light brown, 2.70 long, 2.10 wide and 1.65 high. Ocular quadrangle 1.65 long. Anterior eye row 2.05 wide and posterior 1.90 


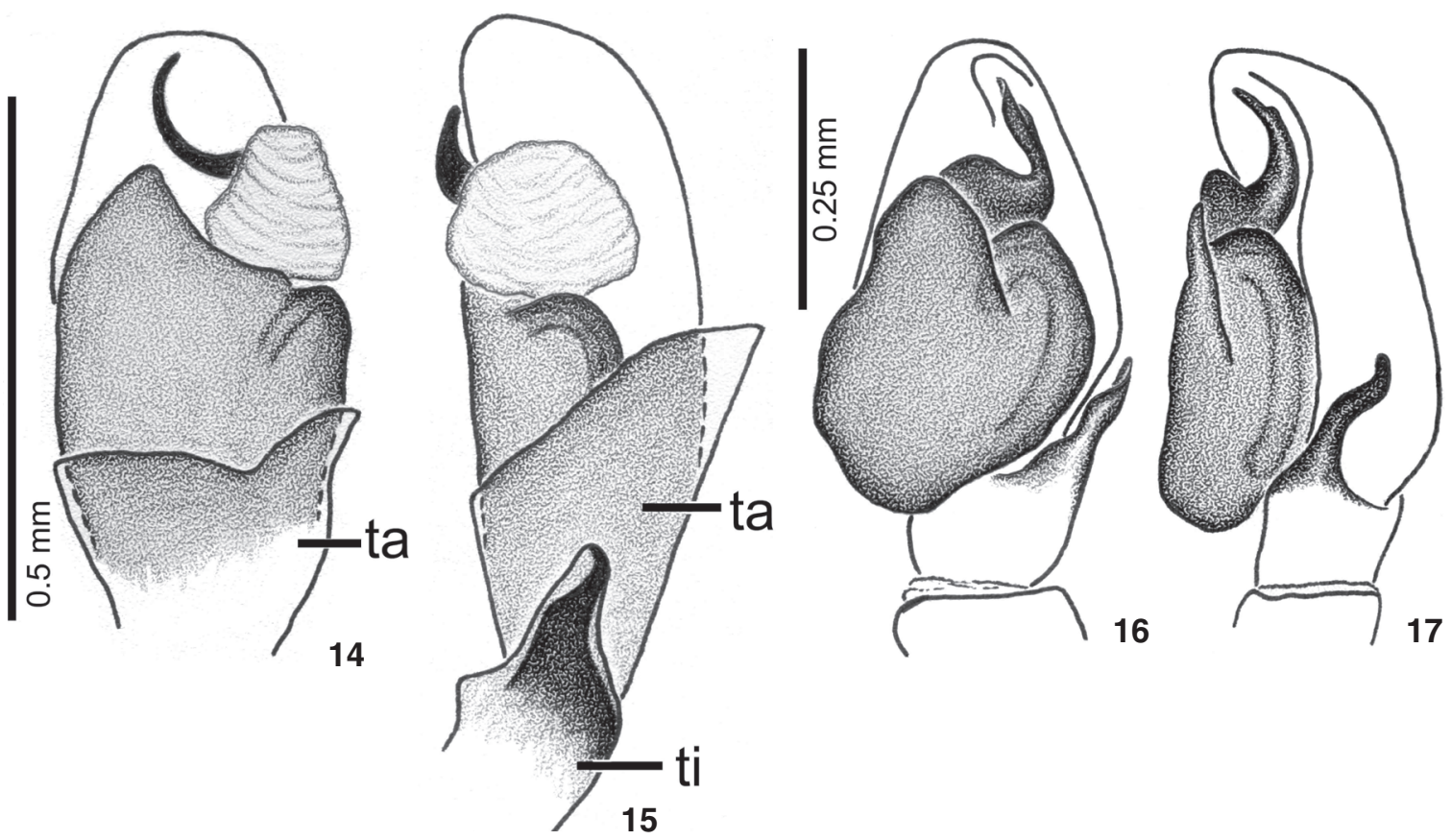

Figures 14-17. (14-15) Naubolus melloleitaoi: (14) subadult male palp, ventral view; (15) retrolateral view; (16-17) Sassacus leucomystax: (16) male palp, ventral view, (17) retrolateral view. (ta) Exoskeleton of penultimate palpal tarsus, (ti) exoskeleton of penultimate palpal tibia.

wide. Chelicerae light brown, stout, with two separate posterior and two anterior teeth. Palps (Figs 18-19) typically euophryine, with moderately long tibia, serrated RTA and coiled embolus; palpal femur curved (Fig. 19). Legs I-II light brown, III-IV yellow. Abdomen yellow.

Female. Unknown.

Remarks. Species of Lapsias do not belong in Salticoida and have median apophyses in the male palp. Because of the coiled embolus and the extra loop in the sperm duct, this species clearly belongs in the subfamily Euophryinae. Since this male has two separate teeth on the retromargin, we tentatively transfer this species to the genus Cobanus F.O.P.-Cambridge, 1900, although the chelicerae are not enlarged.

\section{Corythalia hadzji Caporiacco, 1947} Figs 20-21

Corythalia hadzji Caporiacco, 1947: 33 (Male lectotype and male paralectotype, here designated, from Curupucari, Cumins Lodge, Guyana, XI.1931, Beccari leg., deposited in MZLS 587 and from Conwarook, Potaro, 18.V.1936, C. Romiti leg., deposited in MZLS 588, respectively, examined); Caporiacco, 1948: 721, figs 154155; Berdondini \& Whitman, 2002: 146; Platnick, 2008. Corythalia hadzii; Roewer, 1955: 1102.

Description. Male (lectotype). Total length 4.90. Carapace 2.35 long, 1.70 wide and 1.25 high. Ocular quadrangle 1.07 long. Anterior eye row 1.50 wide and posterior 1.45 wide. Body entirely very dark, except for the light brown tarsi. Chelicerae in bad con- dition. Palp (Figs 20-21) with a RTA with a distal median spine and two lateral (dorsal and ventral) rows of three spines. Legs 4321. Legs II and IV ventrally covered with very dense hairs. Length of femur I 1.30, II 1.40, III 1.80, IV 1.75; patella + tibia I 1.45, II 1.50, III 1.87, IV 1.95; metatarsus + tarsus I 1.20, II 1.20, III 1.75, IV 1.90. Typical carapace and abdominal scales poorly preserved. Female. Unknown.

\section{Corythalia Iuctuosa Caporiacco, 1954}

Figs 22-23

Corythalia luctuosa Caporiacco, 1954: 177, figs 66, 66a (Male lectotype and male paralectotype from Charvein, French Guiana, 1914, R. Benoist leg., respectively deposited in MZLS 655, examined, and MNHN, lost, not examined); Berdondini \& Whitman, 2002: 147; Platnick, 2008.

Description. Male (lectotype). Total length 4.25. Carapace 2.32 long, 1.62 wide and 1.22 high. Ocular quadrangle 1.05 long. Anterior eye row 1.53 wide and posterior 1.41 wide. Body entirely very dark, except for the light brown tarsi. Chelicerae with a row of strong hairs on the promargin and a very small tooth on the retromargin. Palp (Figs 22-23) with an acute ventral tibial apophysis. Legs 3421 . Legs II and IV ventrally covered with very dense hairs. Length of femur I 1.40, II 1.10, III 1.65, IV 1.45; patella + tibia I 1.35, II 1.40, III 1.80, IV 1.60; metatarsus + tarsus I 1.05, II 1.20 , III 1.65, IV 1.65. Typical carapace and abdominal scales poorly preserved.

Female. Unknown. 

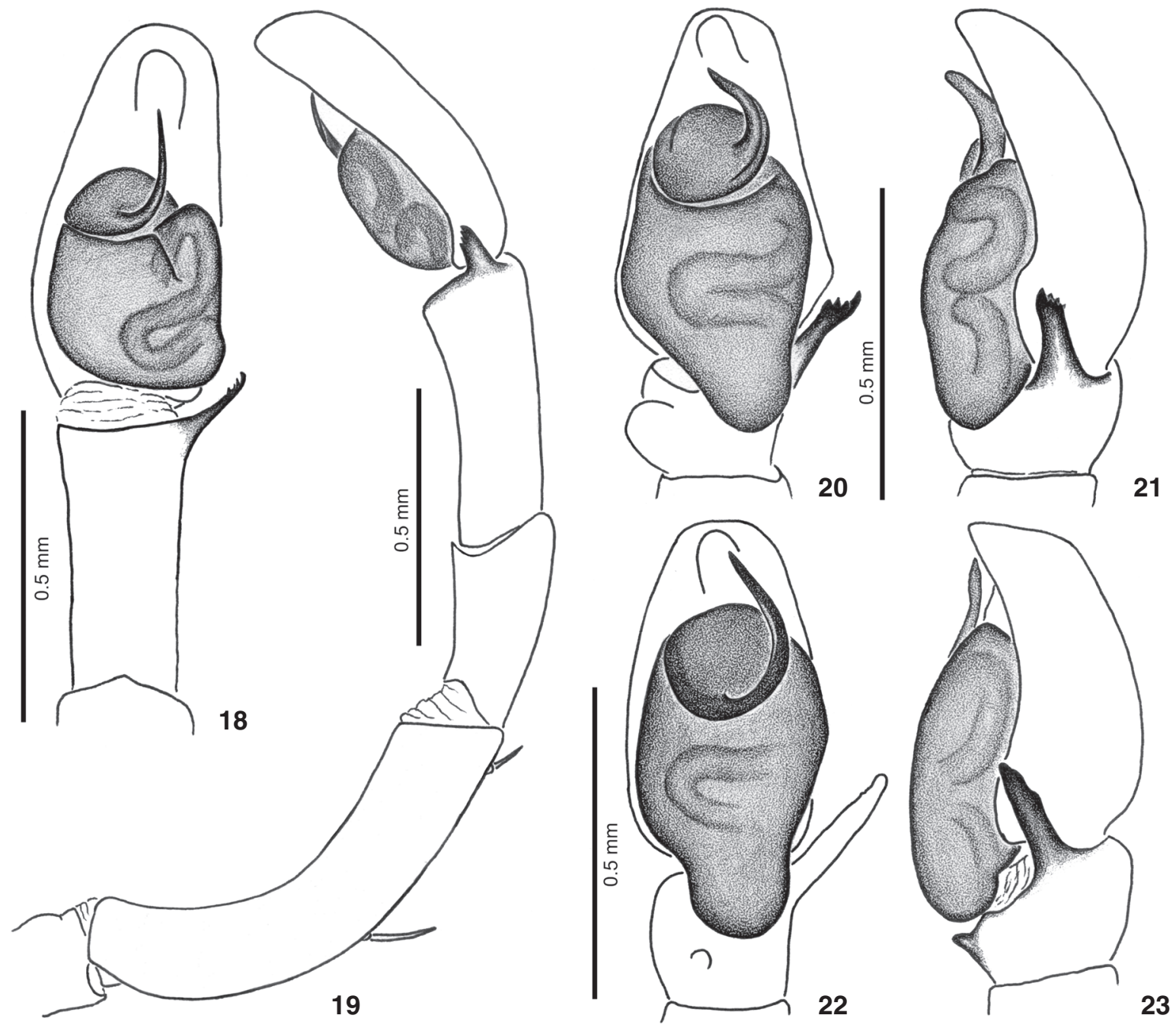

Figures 18-23. (18-19) Cobanus guianensis: (18) male palp, ventral view; (19) retrolateral view; (20-21) Corythalia hadzji: (20) male palp, ventral view; (21) retrolateral view; (22-23) Corythalia luctuosa: (22) male palp, ventral view; (23) retrolateral view.

\section{Freya-group}

\section{Chira spinipes (Taczanowski, 1871)}

Attus spinipes Taczanowski, 1871: 65 (One male, one female and one juvenile syntypes from Cayenne, French Guiana, Jelski leg., deposited in Polska Akademia Nauk, Warsaw, not examined).

Amycus spinipes; Petrunkevitch, 1911: 593.

Capidava spinipes; Mello-Leitão, 1948: 188.

Chira spinipes; Galiano, 1968a: 353, figs 10-14, 17; Platnick, 2008.

Freya guianensis Caporiacco, 1947: 32 (Male lectotype from Campo II, Demerara River, Canister Falls, Guyana, V.1931, Beccari leg., deposited in MZLS 554, examined); Caporiacco, 1948: 718, fig. 149; Caporiacco, 1955: 431, figs 72a-b; Berdondini \& Whitman, 2002: 146; Platnick, 2008. Syn. nov.
Note. The new synonymy is established based on comparisons between Caporiacco's type and illustrations of Taczanowski's species by GaLiano (1968a, figs 10-14, 17). This species does not belong with the rest of the species in Chira and its inclusion in this genus is considered temporary.

Description. See Galiano 1968a, figs 10-14, 17.

\section{Unrecognizable species}

The following nominal species are here considered nomina dubia, either because their types are too juvenile or because they are lost and the illustrations provided in the literature do not allow their recognition.

Albionella guianensis Caporiacco, 1954: 151, fig. 49 (Female and juvenile syntypes from Charvein, French Guiana, XII.1913, R. Benoist leg., respectively deposited in MNHN, lost, and 
MZLS 651, examined); Berdondini \& Whitman, 2002: 146; Platnick, 2008.

Alcmena trifasciata Caporiacco, 1954: 181, fig. 68 (Female and juvenile syntypes from Saint Jean du Maroni and Charvein, French Guiana, respectively, Benoist leg., 1914, respectively deposited in MNHN, lost, and MZLS 656, examined); Platnick, 2008.

Amycus effeminatus Caporiacco, 1954: 154, figs 51, 51a (Female holotype from Charvein, French Guiana, 1914, R. Benoist leg., deposited in MNHN, lost, not examined); Platnick, 2008.

Capidava variegata Caporiacco, 1954: 173, fig. 63 (Juvenile holotype from Akrouménage, Rive Gauche, French Guiana, 29.XII.1948, Mission Aubert de la Rue leg., deposited in MNHN, lost, not examined); Platnick, 2008.

Corythalia variegata Caporiacco, 1954: 179, fig. 67 (Juvenile holotype from Charvein, French Guiana, XII.1913, R. Benoist leg., deposited in MNHN, lost, not examined); Platnick, 2008.

Dendryphantes coccineocinctus Caporiacco, 1954: 187, fig. 72 (Female holotype from Maripa, Oyapock, French Guiana, 3.IV.1948, Mission Aubert de la Rue leg., deposited in MNHN, lost, not examined); Platnick, 2008.

Dendryphantes gertschi Caporiacco, 1947: 33 (Juvenile holotype from Webecari Mission, Essequibo, Guyana, 3.IV.1936, C. Romiti leg., deposited in MZLS 560, examined); Platnick, 2008.

Dendryphantes spinosissimus Caporiacco, 1954: 186, fig. 71 (Female holotype from Charvein, French Guiana, XII.1913, Benoist leg., deposited in MNHN, lost, not examined); Platnick, 2008.

Ilargus modestus Caporiacco, 1947: 33 (Female holotype from Demerara, Guyana, 1931 or 1936, deposited in MZLS, lost, not examined); Caporiacco, 1948: 720, figs 152-153; Platnick, 2008.

Lapsias melanopygus Caporiacco, 1947: 30 (Juvenile holotype from Two Mouths, Essequibo River, Guyana, 14.VII.1936, C. Romiti leg., deposited in MZLS 559, examined); Caporiacco, 1948: 702; Berdondini \& Whitman, 2002: 147; Platnick, 2008. Note. Transferred herein to Frigga C.L. Koch, 1850, resulting in the new combination Frigga melanopygus (Caporiacco, 1947) comb. nov. Although it is possible to determine the genus based on the abdominal color pattern, there are at least two species that occur in this area. The specimen is too juvenile to be identified and the species must be treated as inquirenda.

Lurio splendidissimus Caporiacco, 1954: 188, fig. 73 (Female holotype from Saint Jean du Maroni, French Guiana, 1914, Benoist leg., deposited in MNHN, lost, not examined); Platnick, 2008.

Nagaina modesta Caporiacco, 1954: 192, fig. 75 (Female holotype from Charvein, French Guiana, 1914, Benoist leg., deposited in MNHN, lost, not examined); Platnick, 2008.

Noegus patellaris Caporiacco, 1954: 164, figs 57, 57a (Male holotype from Haute Vallée de l'Oyapock, French Guiana, III.1949, Mission Aubert de la Rue leg., deposited in MNHN, lost, not examined). Transferred to Amycus C.L. Koch, 1846 by Galiano 1968b: 280; Platnick, 2008.
Phidippus triangulifer Caporiacco, 1954: 184, fig. 70 (Female holotype from Le Moult, French Guiana, 1909, deposited in MNHN, lost, not examined); Platnick, 2008.

Tutelina iridea Caporiacco, 1954: 180 (Juvenile holotype from Saint Jean du Maroni, French Guiana, 1914, Benoist leg., deposited in MNHN, lost, not examined); Platnick, 2008.

\section{ACKNOWLEDGMENTS}

To FAPESP (process 06/55226-0) and CNPq for financial support. To the curator of the Museo Zoologico de "La Specola", Sarah Whitman, for sending the type specimens, and G.B. Edwards for comments on the manuscript. This study was developed in the Programa de Pós-Graduação do Instituto de Biociências da Universidade de São Paulo.

\section{LITERATURE CITED}

Berdondini, I. \& S. Whitman. 2002. Cataloghi del Museo di Storia Naturale dell Università di Firenze - sezione di zoologia "La Specola". XVI. Arachnida, Araneae: Tipi. Atti de la Società Toscana di Scienze Naturali 109: 119-156.

Caporiacco, L. Di. 1938. Aracnidi del Messico, di Guatemala e Honduras britannico. Atti de la Società Italiana di Scienze Naturali 77: 251-282.

CAPORIACCO, L. DI. 1947. Diagnosi preliminari de specie nuove di aracnidi della Guiana Britannica raccolte dai professori Beccari e Romiti. Monitore Zoologico Italiano 56: 20-34.

Caporiacco, L. DI. 1948. Arachnida of British Guiana collected in 1931 and 1936 by Professors Beccari and Romiti. Proceedings of the Zoological Society of London 118: 607-747.

Caporiacco, L. DI. 1954. Araignées de la Guyane Française du Muséum d'Histoire Naturelle de Paris. Commentationes Pontificiae Academiae Scientiarum 16: 45-193.

CAPORIACCO, L. DI. 1955. Estudios sobre los aracnidos de Venezuela. 2a parte: Araneae. Acta biologica venezuelica 1: 265-448.

Galiano, M.E. 1963a. Las especies americanas de arañas de la familia Salticidae descriptas por Eugène Simon: Redescripciones basadas en los ejemplares típicos. Physis 23: 273-470.

Galiano, M.E. 1963b. Revisión del género Agelista Simon, 1900, con nota sobre Titanattus notabilis (Mello-Leitão) comb. nov. (Araneae, Salticidae). Physis 24: 29-34.

Galiano, M.E. 1968a. Adiciones a la revision del género Chira Peckham, 1896 (Araneae, Salticidae). Physis 27: 349-366.

Galiano, M.E. 1968b. Revisión de los géneros Acragas, Amycus, Encolpius, Hypaeus, Mago y Noegus (Salticidae, Araneae). Revista del Museo Argentino de Ciencias Naturales Bernardino Rividavia 2: 267-360.

Platnick, N.I. 2008. The world spider catalog, version 8.5. New York, American Museum of Natural History, available online at http://research.amnh.org/entomology/spiders/ catalog/index.html

Petrunkevitch, A. 1911. A synonymic index-catalogue of spiders of North, Central and South America with all adjacent 
islands, Greeland, Bermuda, West Indies, Terra del Fuego, Galapagos, etc. Bulletin of the American Museum of Natural History 29: 1-791.

Roewer, C.F. 1955. Katalog der Araneen von 1758 bis 1940, bzw. 1954. Bruxelles, vol. 2, p. 1-1751.

Ruiz, G.R.S. \& A.D. Brescovit. 2005. Notes on the Venezuelan jumping spiders described by Caporiacco (Araneae, Salti- cidae). Revista Brasileira de Zoologia 22: 753-760.

Ruiz, G.R.S., A.D. Brescovit \& A.A. Lise. 2007. On the taxonomy of some neotropical species of jumping spiders described by Caporiacco (Araneae, Salticidae). Revista Brasileira de Zoologia 24: 376-381.

TACZANowski, L. 1871. Les aranéides de la Guyane française. Horae Societatis Entomologicae Rossica 8: 32-132.

Submitted: 10.III.2008; Accepted: 25.VIII.2008.

Editorial responsibility: Walter A.P. Boeger 